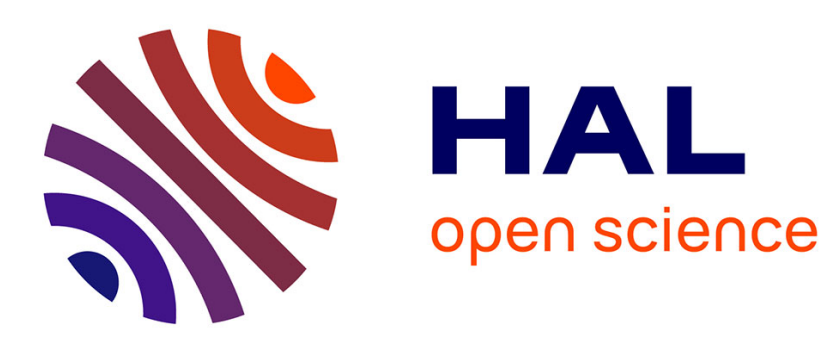

\title{
Transpiration of silver Fir (Abies alba mill.) during and after drought in relation to soil properties in a Mediterranean mountain area
}

Marie Nourtier, Andre Chanzy, Maxime Cailleret, Xie Yingge, Roland Huc, Hendrik Davi

\section{To cite this version:}

Marie Nourtier, Andre Chanzy, Maxime Cailleret, Xie Yingge, Roland Huc, et al.. Transpiration of silver Fir (Abies alba mill.) during and after drought in relation to soil properties in a Mediterranean mountain area. Annals of Forest Science, 2014, 71 (6), pp.683-695. 10.1007/s13595-012-0229-9 . hal-01102695

\section{HAL Id: hal-01102695 \\ https://hal.science/hal-01102695}

Submitted on 13 Jan 2015

HAL is a multi-disciplinary open access archive for the deposit and dissemination of scientific research documents, whether they are published or not. The documents may come from teaching and research institutions in France or abroad, or from public or private research centers.
L'archive ouverte pluridisciplinaire HAL, est destinée au dépôt et à la diffusion de documents scientifiques de niveau recherche, publiés ou non, émanant des établissements d'enseignement et de recherche français ou étrangers, des laboratoires publics ou privés. 


\title{
Transpiration of silver Fir (Abies alba mill.) during and after drought in relation to soil properties in a Mediterranean mountain area
}

\author{
Marie Nourtier • André Chanzy • Maxime Cailleret • \\ Xie Yingge $\cdot$ Roland Huc $\cdot$ Hendrik Davi
}

Received: 28 February 2012 / Accepted: 16 July 2012 /Published online: 21 August 2012

(C) INRA / Springer-Verlag France 2012

\begin{abstract}
- Context Silver fir is declining and dying at its southern margin on the Mediterranean area, where climate is expected to be warmer and drier. At a regional scale, silver fir seems to be vulnerable to drought, and at a forest stand scale, tree death seems to be distributed according to soil water availability.

- Aim To understand the vulnerability of silver fir to drought, factors involved in the regulation of transpiration were
\end{abstract}

\section{Handling Editor: Erwin Dreyer}

Contribution of the co-authors M. Nourtier: experimental design, data collection, data analysis, paper writing

A. Chanzy: experimental design, supervising the work, paper writing

M. Cailleret: experimental design, data collection, data analysis, paper writing

Y. Xie: experimental design, data collection, data analysis

R. Huc: experimental design, data analysis, paper reviewing

H. Davi: experimental design, supervising the work, paper writing

M. Nourtier $\cdot$ A. Chanzy $(\bowtie) \cdot X$. Yingge

UMR1114, Environnement Méditerranéen et Modélisation des

AgroHydrosystèmes, INRA,

Domaine Saint Paul, Site Agroparc,

84914 Avignon, France

e-mail: achanzy@avignon.inra.fr

M. Nourtier $\cdot$ A. Chanzy $\cdot$ X. Yingge

UMR1114, EMMAH,

Université d'Avignon et des Pays de Vaucluse,

84000 Avignon, France

M. Cailleret $\cdot$ R. Huc $\cdot$ H. Davi

UR629, Écologie des Forêts Méditerranéennes, INRA,

Domaine Saint Paul, Site Agroparc,

84914 Avignon, France

X. Yingge

College of science, Northwest A\&F University,

Yangling, Shaanxi, China 712100 assessed with respect to soil properties in order to document the spatial distribution of death rates.

- Methods Soil properties were characterized by electric resistivity measurements. Sap flow density and predawn needle water potential were recorded on sampled trees during several years, and crown specific transpiration was estimated. In addition, the vulnerability of coarse roots and branches to cavitation was quantified.

- Results and conclusion Trees growing on soils with a large water storage capacity were the most vulnerable to drought induced soil water deficits. Transpiration was down-regulated as soon as predawn water potential decreased. The vulnerability to cavitation was low, which protected the trees from run-away xylem embolism. Severe soil water deficits led to a rapid decrease of transpiration, which was still visible the following year. The drop-off in transpiration was mainly due to inner sap flow that almost ceased after the drought on all monitored trees. Our results suggest that root dynamic and the ability of roots to take up water were modified by soil water deficit over several years. Such a regulation scheme needs to be better documented and included in models to address silver fir forest responses to drought.

Keywords Transpiration · Drought · Soil properties · Silver fir · Posteffects

\section{Introduction}

Drought is a major factor driving the tree growth and survival. A decrease in water availability induces decreasing water potential in the xylem, which may lead to hydraulic failure. To avoid xylem embolism, transpiration can be reduced by stomatal closure, at the expense of photosynthesis, while metabolism must be maintained through carbon-consuming 
respiratory processes. Consequently, drought induces a reduction in carbon availability for tree respiration, growth, reproduction, defenses against pathogens, and against insect attacks (McDowell and Sevanto 2010; Bréda et al. 2006). The droughtinduced mortality of trees is thought to be caused by carbon starvation and/or hydraulic failure, but no experimental data have yet confirmed either of these hypotheses (McDowell and Sevanto 2010; Sala et al. 2010). Hence, the process (hydraulic failure and/or carbon starvation) through which drought induces tree decline resides in the stomatal regulation of the tree.

In Mediterranean areas, water availability is the main factor limiting vegetative growth (Zweifel et al. 2006). During the last decades, the frequency, duration, and intensity of summer drought episodes have all increased; according to climate models, these trends are predicted to continue into the future. Even if an increase in forest productivity due to an increase in $\mathrm{CO}_{2}$ concentration and temperatures was predicted for the Mediterranean area (Davi et al. 2006; Delpierre et al. 2009), the observed trend was in reality a decrease in tree growth (Cailleret and Davi 2011; Sarris et al. 2007). Moreover, a dieback or decline of forests has often been observed after severe drought episodes (Bréda et al. 2006; Peñuelas et al. 2001; Lebourgeois et al. 2010). Thus, we may expect massive dieback at a larger frequency and over larger areas. This trend is already observed at a worldwide scale (Allen et al. 2010). A decline in tree vitality is usually expressed by a reduction in total leaf area (defoliation), radial growth (BAI), sapwood area, and quantity of nonstructural carbon compounds. Such reductions are usually reversible. However, in the worst cases, such as when drought is too long, intense, or occurs too frequently, the process becomes irreversible, and the trees die.

Root distribution and the resulting capability of trees to extract water from the soil are essential factors for understanding tree vulnerability to drought (Martinez-Vilalta et al. 2002; Sperry et al. 1998; Bréda et al. 2006), but this distribution is difficult to access. A succession of water stress episodes leads to physiological and morphological adjustments of trees to their local environmental conditions, such as changes in xylem conductivity, changes in the ratios between sapwood area, leaf area, and soil-root exchange area and changes in leaf area index (Bréda et al. 2006; Limousin et al. 2009). Indeed, trees growing in a dry environment seem to adjust their structures to increase the availability of water (uptake and storage) and to reduce their demand for water (Mencuccini and Grace 1995; Bréda et al. 2006; Sperry et al. 1998; Becker 1977). Hence, larger root system development, lower vulnerability to embolism, and lower maximum canopy conductance limit tree vulnerability to drought as shown with modeling approaches (Martinez-Vilalta et al. 2002).

Silver fir (Abies alba Mill.) is highly sensitive to drought and is a species typically affected by drought-induced decline at its southern and lower altitude margins (Aussenac 2002; Battipaglia et al. 2009; Lebourgeois et al. 2010; Peguero-Pina et al. 2007). At Mont Ventoux, a mountain in the Mediterranean area of southern France, strong heterogeneities were observed in silver fir mortality, which reached very high rates on specific plots (Cailleret et al. 2012). In the same way, a large variability was observed in soil water storage capacity typical of karstic areas. The interaction between vulnerability to drought and soil water storage capacity is not evident at a fine scale (intraplot).

The goal of this study is to better understand the role of the soil on silver fir behavior under water stress. This objective led to identify how soil water storage capacity affects the transpiration dynamic and mortality occurrence and to assess the main factors involved in the regulation of whole tree transpiration in silver fir and the delayed effects of drought on this transpiration. We took advantage of the variability in water storage capacity found at Mont Ventoux to address such objectives and therefore explain the spatial distribution of dead silver firs.

\section{Materials and methods}

\subsection{Sites of the study}

This study was conducted on the north-facing slope of Mont

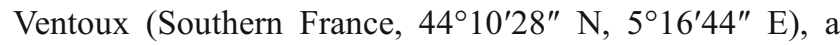
calcareous, Mediterranean mountain. In the mountain vegetation belt (between 1,000 and 1,600 m of altitude), silver fir (A. alba Mill.) colonized pioneer pine stands that had been planted during the nineteenth century. However, during the last decade, silver fir growth declined (Cailleret and Davi 2011), and dead trees or trees displaying large crown damage have been reported. The mortality rate averaged $21 \%$, with a large variability between and within plots $(0-54 \%)$. Mont Ventoux is characterized by a karstic geological formation, and soil thickness above the bedrock is highly variable. Soil water storage capacity is low due to the large proportion of coarse material (between 50 and $80 \%$ ). The climate is a characteristic of a Mediterranean area with dry summers (average summer precipitation over the last 50 years: $100-200 \mathrm{~mm}$, at the foot of the mountain; mean summer temperature: $20-25^{\circ} \mathrm{C}$ ). An increasing trend of summer temperature was observed during the last 50 years (Cailleret and Davi 2011).

Four sites were intensively instrumented at three different altitudes $(1,020,1,100$, and 1,360 m). Soil depths and stone content were different, leading to different water storage capacities that were characterized by $3 \mathrm{D}$ electric resistivity tomography. Measurements of sap flux density on selected trees (a total of nine trees on all sites), soil water content, and micrometeorological conditions were performed during 3 years (2008-2010) at sites A and D and during 2 years (2009-2010) at sites B and C. In 2008 and 2009, predawn and minimum leaf water potentials $\left(\psi_{\mathrm{pd}}\right.$ and $\psi_{\mathrm{min}}$, respectively) of some trees at the different sites were measured 
using a Scholander pressure chamber. Measurements were done on shoot samples (two samples per tree) collected from 18 trees that were located at the different sites, including the nine trees selected for the measurements of sap flux. Characteristics of each site and the description of the measurements are presented in Table 1.

At altitude $1,100 \mathrm{~m}$, a line of $800 \mathrm{~m}$ that transected the contour line (hereafter referred to as the Transect) was also studied to analyze the effects of soil on tree health. Soil properties (characterized with 2D electric resistivity measurements) and the characteristics of the 95 trees (age, height, diameter at breast height, sapwood area, and tree health status) located along the Transect were characterized.

\subsection{Sapwood and projected crown area measurements}

All of the trees in the study were cored at breast height $(130 \mathrm{~cm})$ to the pith and perpendicularly to the slope to avoid compression wood. Cores were extracted during the autumns of 2006 and 2007, before the experimental period, and sapwood was separated from heartwood by color testing with perchloric acid (Kutscha and Sachs 1962). Sapwood length and trunk diameter were measured to determine the sapwood area.

The projected crown area was measured as an estimate of the leaf area developed by each tree. The length of the lowest branches of the crown at four azimuths (south, east, west and north, with the slope oriented toward north) was measured for all sample trees to calculate a mean radius of the circle formed. Variables that were calculated using the projected crown area (such as transpiration) were expressed by square meters of soil.

\subsection{Transpiration measurements and calculation}

Sap flux density was measured for several trees at each site (Table 1) using a thermal dissipation method that was adapted to cyclic heating in order to reduce energy consumption (Nourtier et al. 2011). Heating cycles used in this study were $0.5 \mathrm{~h}$ heating $/ 0.5 \mathrm{~h}$ cooling during night and day in 2008 . These cycles were modified in 2009 and 2010 to $1 \mathrm{~h}$ heating/ $1 \mathrm{~h}$ cooling during day and $3 \mathrm{~h}$ heating $/ 4 \mathrm{~h}$ cooling during night. We applied the approach proposed in Nourtier et al. (2011) to correct for transient warming effects.
As the active length of the probes was $2 \mathrm{~cm}$, only a part of the sap flow was measured when sapwood thickness was larger than $2 \mathrm{~cm}$. Thus, a scaling-up procedure was applied to estimate whole-tree transpiration with an approach similar to that of Delzon et al. (2004). At each site, sap flux density was measured with four sensors on one highly instrumented (HI) sample tree, while it was measured on the other sample trees with one sensor located on the northern side between 0 and $2 \mathrm{~cm}$ below the cambium. For the HI tree, three sensors were inserted at the western, eastern, and northern sides of the tree between 0 and $2 \mathrm{~cm}$ below the cambium $\left(\mathrm{J}_{2}{ }_{2}\right.$ corresponds to the mean of these three sap flux densities in $\mathrm{L} \mathrm{m}^{2} \mathrm{~h}^{-1}$ ), and another sensor was inserted at the northern side between 2 and $4 \mathrm{~cm}\left(J_{2}{ }_{4}\right.$ in L. $\left.\mathrm{m}^{2} \cdot \mathrm{h}^{-1}\right)$ to measure the radial pattern of sap flow density. From the sap flux densities that were calculated at the two depths, a correction factor, $C$, was calculated at each measurement time:

$C=\frac{J_{2 \_} 4}{J_{0 \_}}$

Because the sap flux density was lower in the sapwood between 2 and $4 \mathrm{~cm}$ than between 0 and $2 \mathrm{~cm}$, we assumed that a linear decrease in the sap flux density occurred with depth within the sapwood. The slope of the relationship was given by $C$ and the sap flux density (in $\mathrm{L} \mathrm{dm}^{-2} \mathrm{~h}^{-1}$ ) was computed at each depth (with a step of $2 \mathrm{~cm}$ ) over the sapwood thickness. For the majority of the HI trees, the assumption made for the extrapolation had little impact since it was mostly done over $1 \mathrm{~cm}$ only or even less (see sapwood width on Table 2). Some authors suggest a bell shaped curve ( $\mathrm{Lu}$ et al. 2004) with a maximal sap flux density occurring before the two first centimeters. Nevertheless, a linear decrease seemed appropriate for silver fir of this size (Fiora and Cescatti 2006).

$J_{i \_i+2}=C J_{i-2 \_i}$

In the case of trees instrumented with a single sensor, the $C$ value, calculated for the $\mathrm{HI}$ tree at the same site, was applied to retrieve the deeper sap flux density beyond $2 \mathrm{~cm}$. The use of the $\mathrm{C}$ factor determined on the $\mathrm{HI}$ tree to other trees was

Table 1 Characterizations of soil, trees and the location of each intensive site (plots of $20 \times 20 \mathrm{~m}$ ) and descriptions of the experimental design

\begin{tabular}{|c|c|c|c|c|c|c|c|c|c|c|}
\hline \multirow[t]{2}{*}{ Site } & \multirow[t]{2}{*}{ Altitude (m) } & \multirow{2}{*}{$\begin{array}{l}\text { Total number of trees } \\
\text { with } \mathrm{DBH}>20 \mathrm{~cm}\end{array}$} & \multirow[t]{2}{*}{ Slope } & \multicolumn{3}{|c|}{ Number of trees with measurement of } & \multirow{2}{*}{$\begin{array}{l}\text { Soil humidity } \\
\text { measurement }\end{array}$} & \multicolumn{3}{|c|}{ Mean of trees' } \\
\hline & & & & Sap flux & $\psi_{\mathrm{pd}}$ & $\psi_{\min }$ & & Age (years) & Height (m) & $\mathrm{DBH}(\mathrm{cm})$ \\
\hline A & 1,020 & 21 & $36^{\circ}$ & 3 & 7 & 4 & Yes & 63 & 16 & 28 \\
\hline B & 1,100 & 16 & $47^{\circ}$ & 1 & 2 & & No & 81 & 12 & 25 \\
\hline $\mathrm{C}$ & 1,100 & 20 & $44^{\circ}$ & 1 & 4 & & No & 105 & 15 & 31 \\
\hline $\mathrm{D}$ & 1,360 & 16 & $27^{\circ}$ & 4 & 4 & 5 & Yes & 156 & 15 & 36 \\
\hline
\end{tabular}


Table 2 Comparison of the maximum crown specific transpiration of trees ( $T$ in $\left.\mathrm{mm} \mathrm{h}^{-1}\right)$, predawn water potential $\left(\psi_{\mathrm{pd}}\right.$ in $\left.\mathrm{MPa}\right)$ and development of sapwood and projected crown areas according to the soil classes of resistivity

\begin{tabular}{lllllllll}
\hline $\begin{array}{l}\text { Class of } \\
\text { resistivity }\end{array}$ & Tree no. & $\begin{array}{l}\text { Max } T \text { during } \\
\text { the spring of }\end{array}$ & $\begin{array}{l}\text { Min } \psi_{\text {pd }} \text { in } \\
2009(\mathrm{MPa})\end{array}$ & $\begin{array}{l}\text { Sapwood } \\
\text { width }(\mathrm{cm})\end{array}$ & $\begin{array}{l}\text { Crown pojected } \\
\text { area }\left(\mathrm{m}^{2}\right)\end{array}$ & $\begin{array}{l}\text { Age } \\
\text { (year) }\end{array}$ & $\begin{array}{l}\text { DBH } \\
(\mathrm{cm})\end{array}$ \\
\cline { 3 - 7 } & & 2009 & 2010 & & & & & \\
\hline 1 & B1 & - & 0.069 & -1.99 & 5.1 & 18.3 & 80 & 31 \\
2 & A3 & 0.32 & 0.061 & -0.93 & 10.5 & 24.4 & 76 & 40.9 \\
& D1 & 0.25 & 0.16 & -1.14 & 4.4 & 16 & 157 & 48.2 \\
& D2 & 0.18 & 0.10 & -1.02 & 2.7 & 17.2 & 159 & 42.5 \\
& D3 & 0.22 & 0.19 & -1.17 & 3.6 & 9.9 & 146 & 28.9 \\
& D4 & 0.16 & 0.13 & -0.99 & 3.5 & 15.9 & 161 & 29.1 \\
& A1 & 0.18 & 0.065 & -1.37 & 6.5 & 27.6 & 83 & 41.1 \\
& A2 & 0.15 & 0.074 & -1.27 & 4.7 & 14.6 & 72 & 40.6 \\
& C1 & - & 0.081 & -1.62 & 4.4 & 11 & 82 & 25 \\
\hline
\end{tabular}

supported by Delzon et al. (2004) and Fiora and Cescatti (2006) who have found a relationship between $C$ and the diameters of trunks leading us to expect a similar behavior between trees having comparable diameters. This was the case at site A [mean, $41 \mathrm{~cm}$; standard deviation (SD), $0.29 \mathrm{~cm}$ ], but the heterogeneity in trunk diameter at site D (mean, $37 \mathrm{~cm}$; SD, $9.5 \mathrm{~cm}$ ) may impact the sap flux calculation, and therefore, transpiration levels might not be comparable between the trees.

Total sap flux, $J$ (in $\mathrm{L} \mathrm{h}^{-1}$ ), was then calculated by adding the sap flow of each ring of 2-cm wide sapwood (between $i$ and $i+2)$ :

$J=\sum_{A_{\mathrm{s}}} J_{i_{-i+2}} A_{i_{-} i+2}$

where As is the sapwood area $\left(\mathrm{m}^{2}\right)$ and $A_{i_{-} i+2}$ is the area of the ring between $\mathrm{i}$ and $\mathrm{i}+2 \mathrm{~cm}$.

Finally, the crown specific transpiration of each tree, $T$ (in $\mathrm{mm} \mathrm{h}^{-1}$ ), was obtained by dividing $J$ by the projected crown area of the tree $\left(S, \mathrm{~m}^{2}\right)$. This calculation was preferred to tree transpiration in order to allow the comparison with the potential transpiration computed at the canopy level. In the following, $T$ will be referred to as transpiration.

\subsection{Soil water content}

Soil water content was assessed using direct and indirect measurements. Soil water content profiles were measured at sites A and D. At each site, three pits were dug, and in each of them, five capacitance probes (Decagon EC-10) were installed at 10, 30, 50, 70, and $90 \mathrm{~cm}$. The high stone content prevented a site calibration; the relative extractable water (REW) was then taken as a proxy of the soil water content and was computed according to:

$\mathrm{REW}=\frac{S-S_{\min }}{S_{\max }-S_{\min }} \times 100$ where $S, S_{\min }$, and $S_{\max }$ were the current, minimum, and maximum voltages, respectively, that were delivered by the probes. $S_{\min }$ and $S_{\max }$ were established for every sensor over the 3 years of measurements. As we covered the whole range of soil moisture, from wet and very dry conditions, REW represents the fraction (\%) of the soil water storage that was available for the plant. For a given site, results given by the probes at the same depth were averaged, and a mean value was computed over the profile at each acquisition time.

Predawn needle water potential $\left(\psi_{\mathrm{pd}}, \mathrm{MPa}\right)$ was measured at different dates. This measurement is representative of the mean soil water potential next to the roots because the plant should be in equilibrium with the soil at the end of the night. It was recorded before sunrise between 4:00 and 5:00 A.M. (local time).

\subsection{Characterization of soil properties using electrical resistivity}

As access to the sites and soil sampling were difficult, we used a nondestructive geophysical method to measure the electrical resistivity (ER) of soils. In this method, vertical 2D and 3D ER maps were reconstructed by tomography. ER was measured by injecting a current between two electrodes and measuring the difference of electric potential between two additional electrodes. A set of measurements was combined, and a 2D or 3D model was inverted to retrieve an ER map that minimized the difference between simulations and measurements.

The transect was characterized with 2D measurements. We used a set of 64 electrodes, which were aligned along a 126-m profile with a regular spacing of $2 \mathrm{~m}$ between electrodes and a gradient protocol. Ten profiles were combined to cover the transect $(700 \mathrm{~m})$. They were inverted using the RES2DINV software leading to a $1-\mathrm{m}$ resolution and an investigation depth of approximately $20 \mathrm{~m}$. 
3D measurements were performed on each site to characterize the ER around all the sampled trees. It was done by installing the 64 electrodes onto a square grid, with a $1-\mathrm{m}$ space between the adjacent electrodes. A pole-dipole protocol was used, and measurements were inverted using the RES3DINV software. This inversion led to maps that spanned down to $5 \mathrm{~m}$ and a resolution of approximately $1 \mathrm{~m}$.

ER was positively correlated to the stone volumetric fraction and allows the detection of the soil/bedrock boundary. Assuming that bedrock depth and fraction of coarse material are the main factors influencing soil water capacity, we defined three classes of resistivity to represent three different classes of water storage capacity: class $1,[0,500]$; class 2, [500, 1,000]; and class $3>1,000 \Omega \mathrm{m}^{-1}$. From the ER map, an average was computed for every tree considered in the study. To be consistent with the possible distribution of roots in our study area, ER were averaged over a depth of $5 \mathrm{~m}$ (Rambal 1984; Nijland et al. 2010) and a lateral domain of $4 \mathrm{~m}$ and $16 \mathrm{~m}^{2}$ centered on the tree for 2D and 3D measurements, respectively.

During 2010, 2D ER measurements were repeated from July to October with a $50-\mathrm{cm}$ space between electrodes allowing a spatial resolution of $25 \mathrm{~cm}$. This monitoring enabled to record the temporal variation of soil water content as soil becomes less conductive to electricity when it dries. Measurements were centered on trees A1 and D1, perpendicularly to the slope. Relative differences of resistivity (dimensionless) were calculated at each site between successive profiles. Hence, an increase in the relative difference indicates a soil moistening, whereas a decrease indicates soil drying.

\subsection{Micrometeorological measurements}

At each site, a pole was installed at the top of each HI tree to measure micrometeorological variables approximately $1 \mathrm{~m}$ above canopy. Wind speed $\left(u_{\mathrm{s}}\right)$, air temperature $\left(T_{\mathrm{a}}\right)$, relative humidity $\left(R_{\mathrm{h}}\right)$, and global radiation $\left(R_{\mathrm{g}}\right.$ - only at sites $\mathrm{A}$ and $\mathrm{D})$ were measured every $30 \mathrm{~min}$. Rainfall was also recorded at sites $\mathrm{A}$ and $\mathrm{D}$ (one rain gauge per site with a measurement every $30 \mathrm{~min}$ ) in an open area during the years 2009 and 2010 and below the canopy at site A during the year 2008 .

From these data, a reference transpiration, $T_{0}$, was calculated as the potential transpiration of the canopy using Penman-Monteith equation where the soil heat flux was neglected. To use this equation, it was necessary to estimate, in addition to the measurements, the net radiation $\left(R_{\mathrm{n}}\right)$ and the stomatal resistance $\left(r_{\mathrm{s}}\right)$ of a silver fir under the meteorological conditions measured on sites. $r_{\mathrm{s}}$ was computed using the process-based model CASTANEA (Dufrêne et al. 2005) parameterized for silver fir without water stress (soil water content fixed at its maximum and $R_{\mathrm{h}}$ at $100 \%$ ).
$R_{\mathrm{n}}$ was computed with the model ISBA (Noihlan and Mahfouf 1996) implemented without soil water stress, with measured climatic data and the atmospheric radiation $\left(R_{\mathrm{a}}\right.$ in $\mathrm{W} \mathrm{m}^{-2}$ ) measured at Avignon (a city at approximately $60 \mathrm{~km}$ of the study site). ISBA was not used to calculate $T_{0}$ because we wanted to take into account the ecophysiological control of the transpiration via $r_{\mathrm{s}}$ that is not simulated in this model.

\subsection{Xylem vulnerability to cavitation}

Vulnerability to cavitation was assessed on branches and shallow roots, with the air injection method (Cochard et al. 1992) on eight samples (between 0.8 and $1 \mathrm{~cm}$ of diameter) taken from four healthy trees during a wet period to avoid native cavitation. Four to 9 years old and 1 -cm thick branches were sampled from crown top of 46 trees at sites A and D. Samples were subjected to pressures from 0 to $7 \mathrm{MPa}$, with successive $1 \mathrm{MPa}$ steps. The percent loss of hydraulic conductivity (PLC) was calculated with respect to the maximum conductivity recorded at $0 \mathrm{MPa}$. The resulting vulnerability curve was fitted to an exponential sigmoid (Pammenter and Willigen 1998).

$\operatorname{PLC}=100 /\left[1+e^{a\left(\psi-P_{50}\right)}\right]$

where $\psi$ is the water potential corresponding to the applied pressure, and $a$ and $P_{50}$ are the fitted parameters, $P_{50}$ being the water potential leading to a $50 \%$ loss in hydraulic conductivity.

\subsection{Data analysis}

To test the significance of the differences in transpiration rates, we used a Student's $t$ test on the average of daily maximum transpiration over a 10-day period. To analyze the influence of two factors on a variable, we used a two-way ANOVA, without interaction between factors. Tests were done on the drought 2009, which was the period of interest. To assess the adequacy between the distributions of two series of data we used a $\chi^{2}$ test. For all tests, differences were accepted as significant when $p<0.05$.

\section{Results}

\subsection{Impacts of soil characteristics on tree health}

The fraction dead trees depended on soil properties over the transect. Unexpectedly, there were more dead trees on deep soils (with low resistivity on the five first meters depth) than on soils displaying a larger resistivity (Fig. 1). Class 1, i.e., soils with potentially more available water, displayed the 


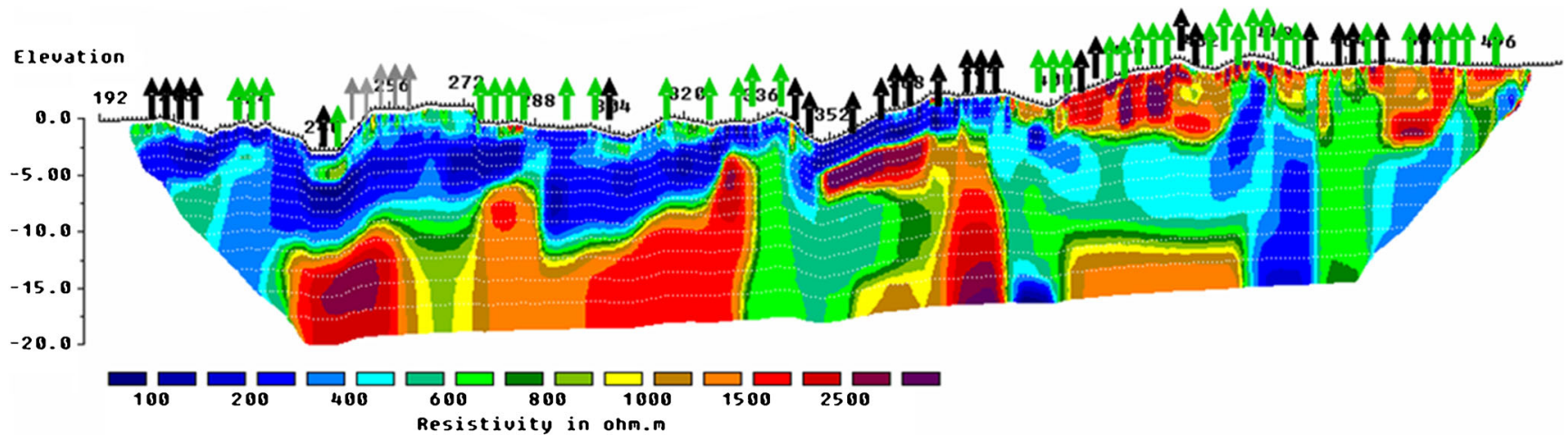

Fig. 1 A 300-m long topographical transect displaying 2D electrical resistivity at different depths (in $\Omega \mathrm{m}$ ) down to $20 \mathrm{~m}$. Health status of trees located on the transect are displayed: black, gray, and green arrows correspond to dead, declining, and healthy trees respectively

highest fraction dead trees (Fig. 2; significant difference between class 1 and the two others: $\chi^{2}$ test, $p<0.05$ ). Classes 2 and 3 , with lower potential water availability, displayed a larger fraction of healthy trees, and a smaller fraction dead trees than class 1 (Fig. 2).

\subsection{Regulation of transpiration, microclimate and soil water content}

$T_{0}$ slightly decreased with elevation: Maximum values were $0.65 \mathrm{~mm} \mathrm{~h}^{-1}$ for site $\mathrm{A}, 0.61 \mathrm{~mm} \mathrm{~h}^{-1}$ for sites $\mathrm{B}$ and $\mathrm{C}$ and $0.58 \mathrm{~mm} \mathrm{~h}^{-1}$ for site D (Fig. 3). Cumulative rainfall (from May to September) was $623 \mathrm{~mm}$ in 2008, $382 \mathrm{~mm}$ in 2009 and $329 \mathrm{~mm}$ in 2010. Water deficit, i.e., cumulated difference between Penman potential evapotranspiration and rainfall, reached $653.2 \mathrm{~mm}$ in 2009 in Avignon and $513.6 \mathrm{~mm}$ in 2010, while it was $411 \mathrm{~mm}$ in 2008. The water deficit of 2009 was $10 \%$ greater than the mean water deficit recorded between 1989 and 2011, but was not exceptional. It ranked 16th over the 23 years (1989-2011) when summer water deficit is sorted in ascendant order. Year 2010 ranked seventh and 2008, which was a specially wet year, ranked second.

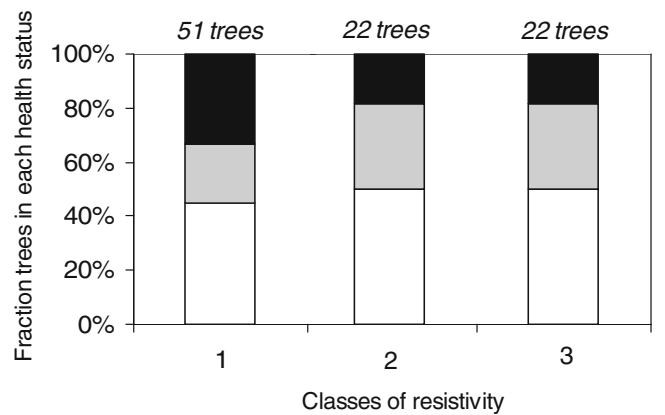

Fig. 2 Health status in the three classes of soil resistivity (total number of trees, 95). Black areas correspond to dead trees, gray areas to declining trees, and white areas to healthy trees. The difference between class 1 and the two others is significant ( $\chi^{2}$ test, $p<0.05$ )
Recorded transpiration was low, and most of the time below $0.25 \mathrm{~mm} \mathrm{~h}^{-1}$ (Table 2) with a $T / T_{0}$ ratio that never exceeded 0.6. This indicates that actual transpiration was strongly down-regulated by low stomatal conductance. Indeed, there was a strong reduction in transpiration during summers 2009 and 2010 in all monitored trees (Figs. 3 and 4). This was not the case in 2008 , when transpiration only moderately decreased during summer (Fig. 3). To test the significance of the differences in $T$ levels between spring and end of summer 2009, two different periods of 10 days were selected: days 195-205 for spring and 245-255 for summer. Differences were significant (Student's $t$ test, $p<$ 0.05 ) for almost all trees with a reduction of $95 \%$ for tree $\mathrm{A} 1,88 \%$ for tree $\mathrm{B} 1$, and $66 \%$ for tree $\mathrm{C} 1$. Tree $\mathrm{D} 1$ was an exception with a reduction of $64 \%$, which was not significant. However, the reduction for this tree was significant when earlier periods in spring (days $145-155$ period) are considered.

Transpiration ratios were well correlated to REW, when it was low $(\mathrm{REW}<20 \%)$. The $R^{2}$ value was 0.61 for site $\mathrm{A}$, when soil water content was below $15 \%$. At site $\mathrm{D}$, the slighter decrease in transpiration ratio led to a smaller $R^{2}$ (0.17) (Fig. 5). When the soil was wetter (REW $>15 \%$ ), VPD was the main factor controlling transpiration that reached low values when VPD exceeded $2 \mathrm{kPa}$ (Fig. 5). As excepted, transpiration was positively correlated to the VPD below $1 \mathrm{kPa}$ and negatively correlated above this threshold (see site D in Fig. 5). The nonlinear lines representing the envelop of the upper boundary $T / T_{0}$ versus VPD scatter plot were similar at both sites A and D (Fig. 5), revealing that the VPD influence on transpiration is not site dependent.

Minimum needle water potential was relatively stable (between -1.5 and $-2 \mathrm{MPa}$ ) and never decreased below $-2 \mathrm{MPa}$ (Fig. 6). However, it was neither measured in sites $\mathrm{B}$ and $\mathrm{C}$ nor the day where we registered the lowest $\psi_{\mathrm{pd}}$ (Fig. 6). We can then suppose that during this day (231), $\psi_{\min }$ in site B was below -2 MPa. However, Guicherd (1994) found 
Fig. 3 Time course over 3 years of $T_{0}$ and rainfall at site $\mathrm{D}$ and transpiration of the $\mathrm{HI}$ sample trees at each site. Braces indicate the spring $(s g)$ and summer $(s u)$
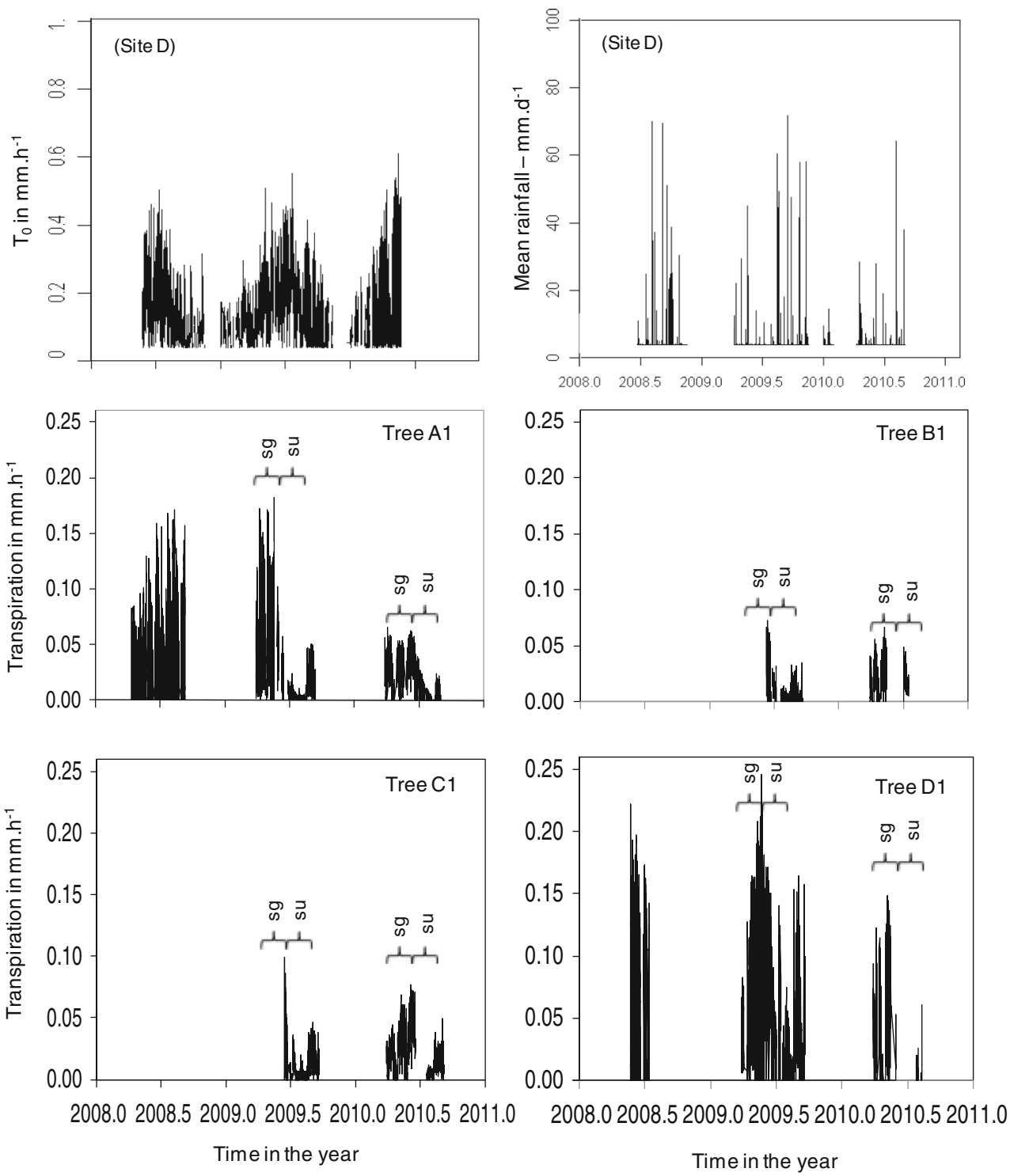

that the transpiration regulation of silver fir allowed maintaining a relatively stable $\psi_{\min }$, which was consistent with our observations. Therefore, $\psi_{\min }$ would probably not decrease strongly below $-2 \mathrm{MPa}$. At this water potential ( $-2 \mathrm{MPa}$ ), the estimated loss in root conductivity was higher than for shoots but remained at a moderate level (16\%; Table 3). Hence, even if the minimum $\psi_{\min }$ is slightly lower than $-2 \mathrm{MPa}$, high embolism rates were avoided during episodes of soil water deficit thanks to the efficient stomatal control of transpiration.

\subsection{Impacts of soil characteristics on tree water fluxes}

Concerning water fluxes, the influence of soil properties was studied by monitoring $T$ and $\psi_{\mathrm{pd}}$ dynamics at the tree level. Tree A3 had higher rates of transpiration because it had larger sapwood area (Tab. 2). As a matter of facts, the $C$ factor was determined from the radial distribution of the sap flux density of tree A1 (shown in Fig. 7) and applied to tree A3. Hence, there might be an overestimation of the factor for this tree. This example shows that the comparison of transpiration rates between trees was questionable. Therefore, we focused on the comparison of the transpiration dynamics.

Trees in class 2 of site D showed a more gradual decrease in transpiration during the drought (Fig. 4) and in less extent with tree A3. This decrease was even thought important, as it corresponded to a reduction of $70 \%$ of the transpiration for tree D1 and $81 \%$ for tree A3, while it was higher than $90 \%$ for trees A1 between the periods $145-155$ and $245-255$ in 2009 . This can be explained by a slightly lower climatic demand at higher altitude (cf. values of $T_{0}$ ) associated to a larger available soil water resource on site D. In the same way, the lower reduction for tree $\mathrm{A} 3$ compared to tree $\mathrm{A} 1$ could be attributed to the different soil conditions. 
Fig. 4 Daily maximum transpiration averaged over periods of 10 days $( \pm \mathrm{SD})$ of selected trees during 2009 and 2010. Braces indicate spring $(s g)$ and summer $(s u)$
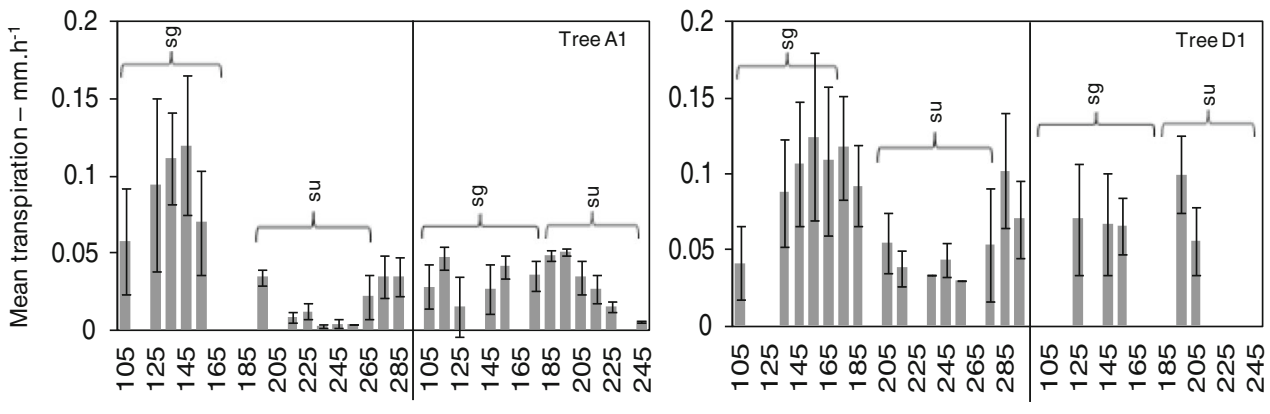

2009

2010

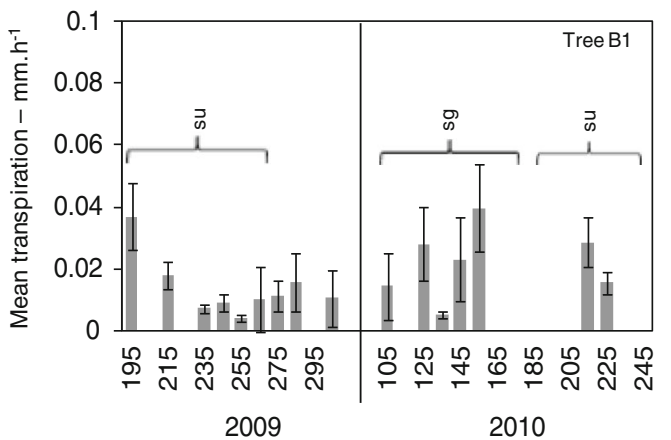

Intervals of time in the year

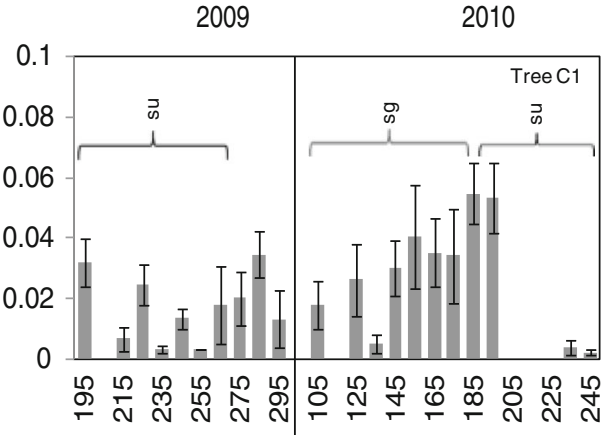

20092010

Intervals of time in the year
The influences of soil classes on the minimal $\psi_{\mathrm{pd}}$ were statistically significant (Fisher's test $p<0.01$ derived from an ANOVA with two factors: altitude that reflects different climatic demand and ER classes), whereas the influence of altitude was not significant $(p>$ 0.5). Among all soil classes, $\psi_{\mathrm{pd}}$ during the drought of 2009 was the lowest for class 1 (Table 2 and Fig. 6) and trees in class 3 showed a $\psi_{\text {pd }}$ significantly higher than that of trees in class 1 , while the $\psi_{\mathrm{pd}}$ of the trees of class 2 remained the highest for the entire drought period (Table 2 and Fig. 6).

\subsection{Lack of transpiration recovery after water stress}

During the winters and springs of 2008-2010, heavy rainfall and snowfall allowed a complete water recharge of the soil
Fig. 5 Impact of relative extractable soil water (REW) and VPD on the transpiration ratio $\left(T^{*}=T / T_{0}\right)$ at noon observed on sites A and D. $R^{2}$ was computed for dry conditions (i.e., REW $<15 \%$ ) for the $T^{*}$ vs. REW relationships (graphs on the left). For the $T^{*}$ vs. VPD relationships, lines correspond to the upper envelop of data (double exponential curve fitted on the highest values for each VPD of both sites). Unfilled points and the gray line correspond to wet soil (REW $>15 \%)$, while filled points and the black line to dry soil REW $<15 \%$.

Only data corresponding to high climatic demand

$\left(T_{0}>0.15 \mathrm{~mm} \mathrm{~h}^{-1}\right.$ and $R_{\mathrm{n}}>$ $400 \mathrm{Wm}^{-2}$ ) are represented
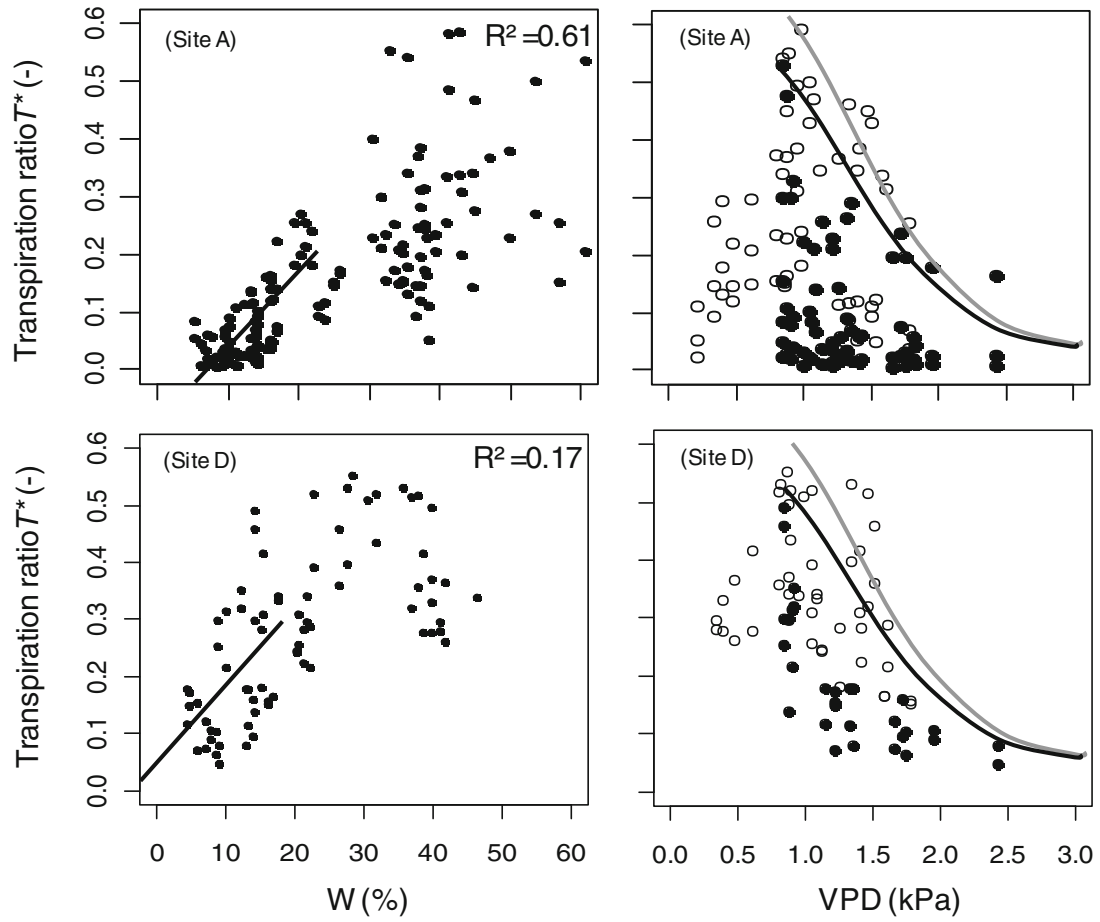
Fig. 6 Time course of the mean $( \pm \mathrm{SD})$ of predawn $(n=3$ for class $1 ; n=9$ for class $2 ; n=6$ for class 3 ) and minimum branch water potential of Abies alba trees at Mont Ventoux on two sites (means for sites A and D; $n=9$ ) according to the classes of soil electrical resistivity

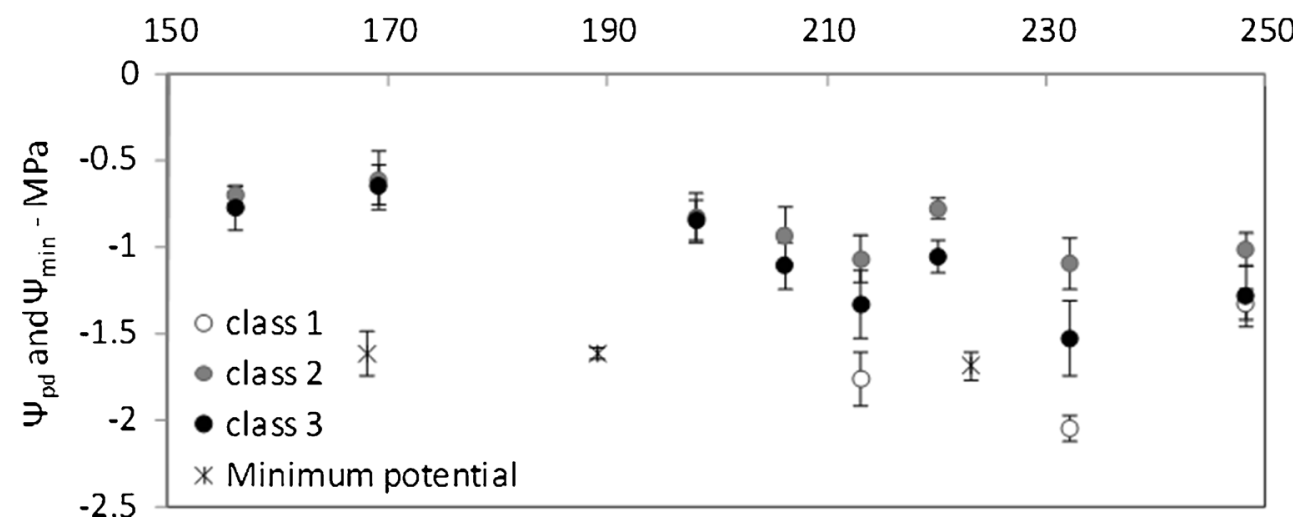

and the levels of $T_{0}$ were similar during the springs of the 3 years (Fig. 3). However, during the beginning of 2010, transpiration rates were clearly lower than those of the springs of 2008 and 2009 (see sites A and D in Figs. 3 and 4, and Table 2). Indeed, differences in daily maximum transpiration between the 10 days long selected periods during the springs of 2009 and 2010 were significant (Student's test, $p<0.05$ ) for tree A1 (a reduction of $82 \%$ between periods of days $145-155$ of both years) and B1 (a reduction of $50 \%$ between the periods 195205 in 2009 and 205-215 in 2010). For tree D1, delayed effects of drought were lighter (a reduction of $46 \%$ between periods of days 145-155 of both years), which is consistent with the smaller transpiration reduction during drought. For tree $\mathrm{C} 1$, we had no enough measurements during the spring of 2009, but transpiration levels in 2010 were low even if they increased at the beginning of the spring (Figs. 3 and 4).

This decrease in transpiration level was mainly due to the loss of sap flux density in the inner sapwood (i.e., recorded by the sensor between 2 and $4 \mathrm{~cm}$ in the sapwood; Fig. 7). Indeed, it felt below $0.05 \mathrm{Ldm}^{-2} \mathrm{~h}^{-1}$ during 2009 drought and remained low (below $0.1 \mathrm{Ldm}^{-2} \mathrm{~h}^{-1}$ at all sites; Fig. 7) during the fall of 2009 , while rainfall watered the soils (Fig. 3). Moreover, the inner sap flow density was maintained low in 2010 despite of the soil water refilling by heavy snowfall. These differences of the inner sap flux density levels between springs of 2009 and 2010 were

Table 3 Parameters for the vulnerability of trees to embolism that are estimated for roots $(n=8)$ and shoots $(n=46)$ from the established vulnerability curves and minimum value of $\psi_{\mathrm{min}}$, which was measured on shoots during the years 2008 and 2009

\begin{tabular}{lccc}
\hline & $P_{50}(\mathrm{MPa})$ & Minimum $\psi_{\min }(\mathrm{MPa})$ & PLC at $\psi_{\min }(\%)$ \\
\hline Shoot & -4.85 & -2.03 & 14 \\
Root & -3.78 & & $16^{\mathrm{a}}$ \\
\hline
\end{tabular}

${ }^{a}$ Estimated from the minimum $\psi_{\min }$ measured on branches significant for all trees (Student's test on the average of daily maximum sap flux densities over the periods described before, $p<0.05$ ) except for tree $\mathrm{C} 1$. In the outer sapwood, the decrease in sap flux density was lighter between the springs of the 2 years: $26 \%$ for tree A1 and $44 \%$ for tree D1 (selected days, 145-155 for both years) and stay relatively stable for trees B1 and increase with tree C1 (selected days, 195-205 for both years; Fig. 7). Therefore, after the drought, the sap was conducted on only a 2-cm wide area of the sapwood for most of the HI trees that were monitored for the sap flux radial distribution (Fig. 7). During the spring of 2010, an increase in the sap flux density of the inner sapwood was however observed for tree $\mathrm{C} 1$, showing that the loss of sap conduction in inner sap flow could be reversible. This tree corresponds to the one with the highest ER value, i.e., a rocky soil, among the intensively monitored tress. Besides, the small decrease in the sap flux density between 0 and $2 \mathrm{~cm}$ after 2009 drought was accentuated after 2010 drought on trees A1 and C1 (Fig. 7).

\subsection{Evolution of soil water content on vertical profiles}

At site A, between 1 and $3.5 \mathrm{~m}$ of depth in the soil, there was a pocket with low resistivity and so a higher potential water content (Fig. 8). The relative difference of resistivity between July and August of 2010 indicated that this area was drying faster. Therefore, trees above this pocket would preferentially uptake water into it. At site D, the drying of the soil between July and August was more homogeneous, as was the structure of the soil. Hence, tree water uptake between these 2 months seemed to be distributed homogeneously over the $4 \mathrm{~m}$ of soil.

After rainfall at the end of the summer, the soil moistening was principally localized within the first meter at site D, while it seemed to penetrate deeper at site A, probably by 
Fig. 7 Radial distribution of the sap flux density represented by hourly values of sap flux densities at two depths in the sapwood. Gray and black lines correspond to the sensors between $0-2 \mathrm{~cm}$ and $2-4 \mathrm{~cm}$ into the trunk, respectively. Braces indicate the periods of spring $(s g)$ and summer $(s u)$
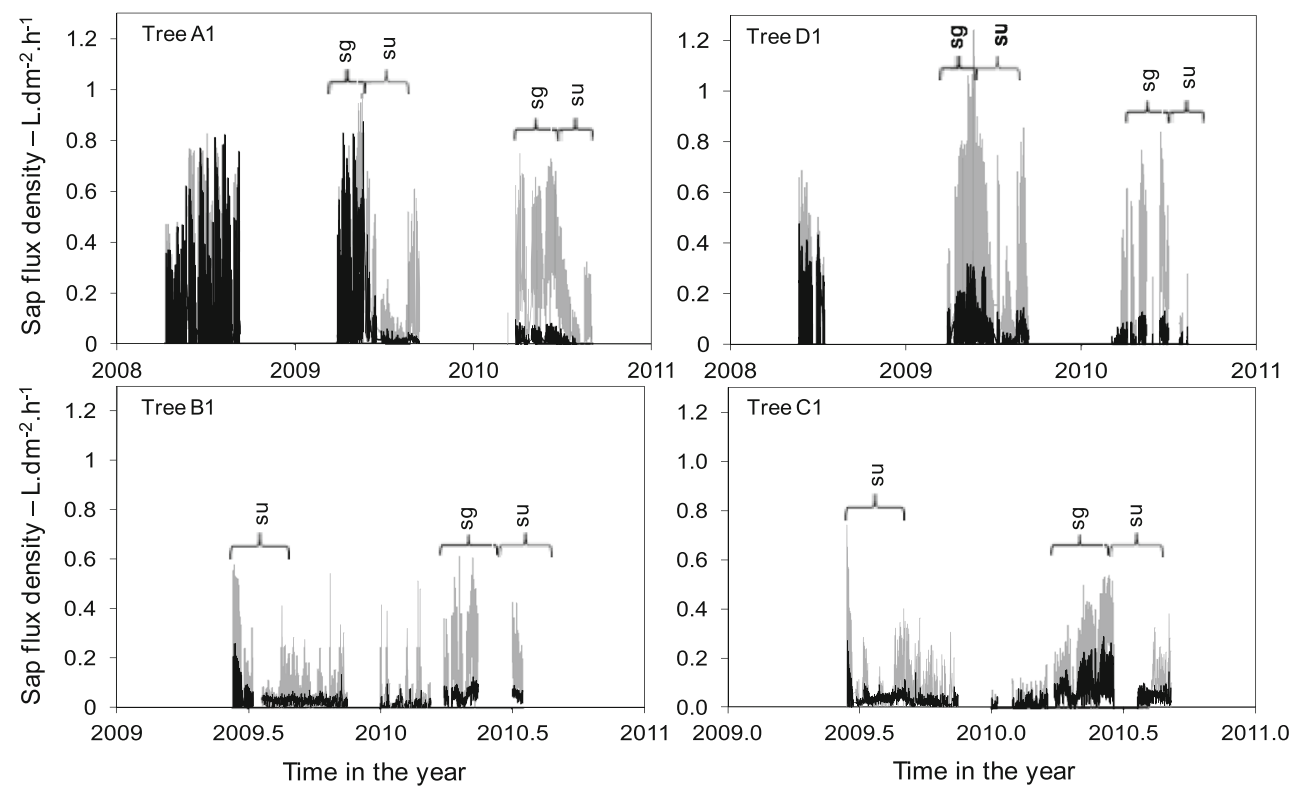

following cracks in the soil. Nevertheless, the main moistening at site A was localized within the first $50 \mathrm{~cm}$. Between September and October, the soil water content stayed relatively constant. Indeed, the transpiration of the trees was reduced and the frequency of rainfall increased in comparison to the summer.
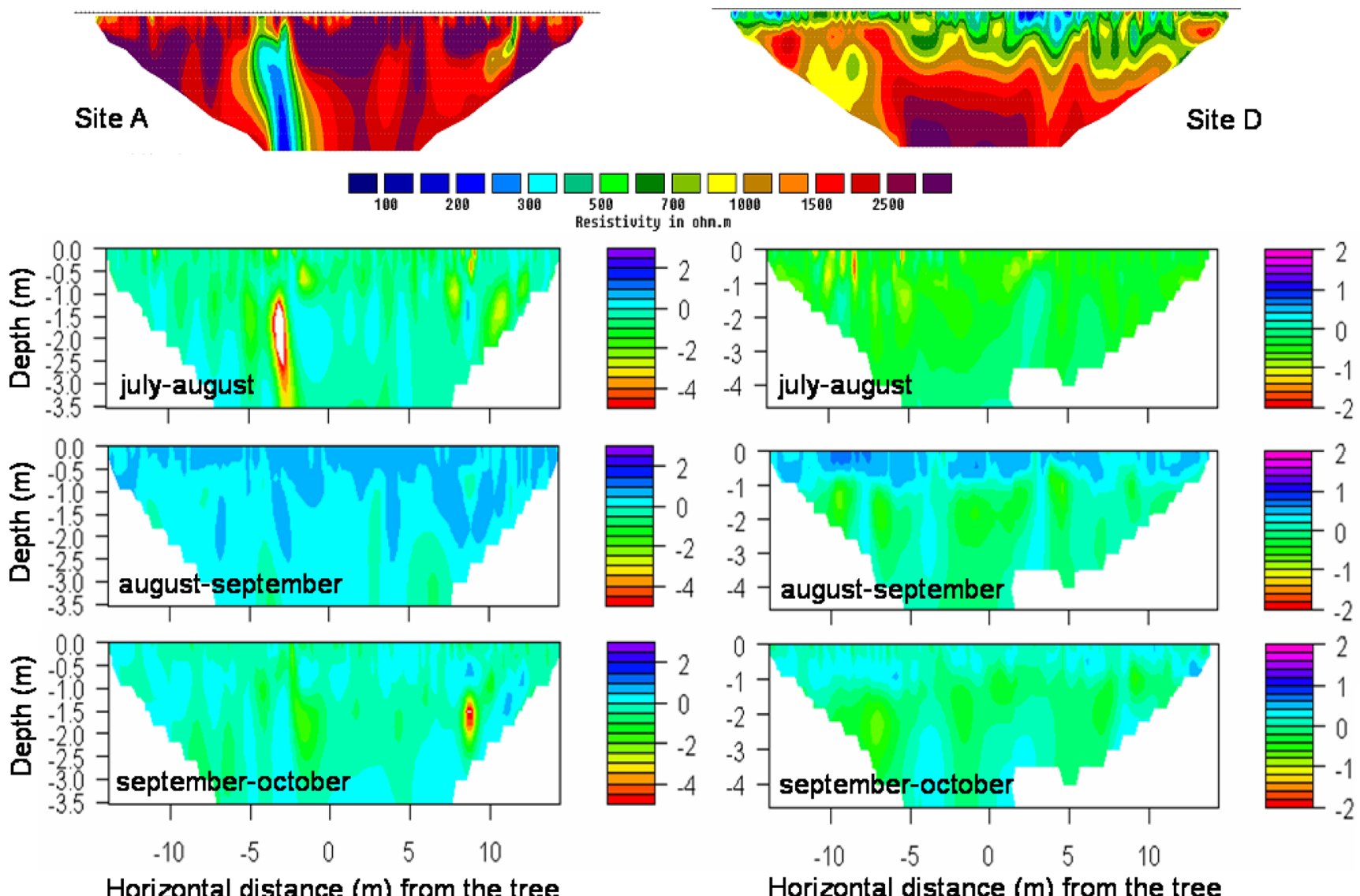

Fig. 8 Relative differences in electric resistivity at sites A (on the left) and D (on the right) between dates (15th of July, 12th of August, 13th of September, and 8th of October of 2010). The color scale represents

the relative difference (dimensionless), and the two profiles on the top of the figure correspond to the initial measurements of resistivity (in $\Omega \mathrm{m}$ ) during July 


\section{Discussion}

4.1 Transpiration regulation of silver fir and vulnerability to drought

Our results indicate that silver fir regulates its transpiration strongly as mentioned by previous studies (Aussenac 2002, Peguero-Pina et al. 2007, Guicherd 1994). The minimum water potential we observed was similar to Guicherd's (1994) observations $(-1.8 \mathrm{MPa})$, but our transpiration measurements were far lower than those obtained on silver fir in the Alps and the Apennines (Guicherd 1994; Piovani et al. 2011). This could be due to errors in scaling up of the sap flux density. However, the measured sap flux densities were lower than those usually reported for coniferous species, which are between 1 and $2 \mathrm{Ldm}^{-2} \mathrm{~h}^{-1}$ (Cermak et al. 2008; Köstner at al. 1998; Nadezhdina et al. 2007). Another explanation is the constraining environmental conditions with successive droughts that could have weakened the trees and reduced the transpiration rate.

At the minimum water potential, a small loss of conductivity was expected, but part of the organ are still be damaged by embolism. Besides, the strong stomatal control led to very low levels of transpiration $\left(<0.05 \mathrm{~mm} \mathrm{~h}^{-1}\right.$ for more than 1.5 months in 2009) and also reduced the photosynthesis and then the carbon availability. Therefore, trees became more dependent on nonstructural carbohydrate reserves that would limit the renewal of needles and roots during and after drought. Moreover, the carbon loss would lead to a decrease in tree defenses against pathogens. Indeed, bark beetles were present at Mont Ventoux and significantly speeded up the decline in vitality for previously weakened trees, leading to quick death (Gillmann et al. 2012).

\subsection{Delayed effects of drought on water uptake}

The strong sap flow reduction (more than $80 \%$ for trees A1 and D1) within the inner xylem was the main cause of the transpiration drop-off after drought revealing its long-term effects. As sap flow recovery was observed on tree $\mathrm{C} 1$ and because of the low vulnerability of silver fir to cavitation, this drop-off would not result from large sapwood embolism, which is not reversible for conifers.

Transpiration reduction could be due to significant loss of needles that usually occurred during drought (Bréda et al. 2006; Limousin et al. 2009). However, this was not observed during this study. Another hypothesis would be a decrease in photosynthetic capacities of needles during drought, with an incomplete recovery due to limitations by the nitrogen concentration and/or by the lack of chlorophyll restoration (Heckathorn et al. 1997; Montagu and Woo 1999). This would limit transpiration without immediate loss of needles and would mainly occur on lower branches, which can be connected to the inner sapwood (Fiora and Cescatti 2006; Nadezhdina 2010).

The inner sap flux density drop-off could also be caused by a decrease in water uptake by the roots. Water transported within the inner sapwood was found to be related to the water absorbed by deep roots for maple trees and scot pines (Nadezhdina 2010; Cermak et al. 2008). Our results can then be interpreted as follows. After the first rainfall events following the drought of 2009, water uptakes were made in soil surface layers since deep layers were not watered (Fig. 8). This cannot explain the lack of sap flow recovery in 2010, since the soil was well watered during the winter with high levels of snowfall. Therefore, the root system might have been damaged during the drought by moderate root embolism together with an increase in fine root mortality (Mainiero and Kazda 2006; Olesinki et al. 2011) and/or the roots might be insufficiently regenerated during and after the drought due to carbon starvation (Lebourgeois et al. 1998; Becker 1977). These phenomena would be accentuated in the deeper soil layer. Indeed, deep roots were found to be more vulnerable to embolism (McElrone et al. 2004), and Mainiero and Kazda (2006) have shown that carbon could preferentially be allocated to the shallow roots to favor the exploitation of hydro mineral resources.

The loss of photosynthetic capacity and the alterations of the root system may occur together. However, the recovery of the $\mathrm{C} 1$ tree lets us think that the last hypothesis is more plausible. Indeed, located on a rocky soil, this tree quickly encountered a lack of water availability near the surface and, therefore, would have allocated more carbon to deep roots as an adjustment to the local soil water properties.

\subsection{Effect of soil properties on tree sensitivity and vulnerability to drought}

As suggested by lower $\Psi_{\mathrm{pd}}$, trees on soils with larger water storage capacities (ER class 1) were subjected to higher and earlier water stress during drought. This behavior can be related to the strong mortality rates observed on these soils. It could be explained by a shallow root system and/or a greater root/needle area ratio. On these soils, the root system development would have been sufficient to fulfill water needs in normal climatic conditions, i.e., those met during the juvenile period, but would not be adapted for repeated drought conditions as met during the last decade.

Each time it occurs, drought induces damages to the root system, resulting in a decrease in transpiration and then of carbon availability. Thus, an adjustment of the root system to drought conditions would not be possible after a severe water stress event, since carbon resources would be mobilized to recover the existing system. Hence, trees located on soils of class 1 , subjected to the highest water stress, would suffer from stronger damages and would dispose of less 
carbon to recover, explaining their higher mortality in case of repeated drought as during the last decade.

\section{Conclusions}

This study showed some physiological responses to drought of silver fir trees at Mont Ventoux. The "patchy" distribution of dead trees at the study site was correlated to the heterogeneity of the soil properties. Unexpectedly, trees were the most vulnerable on soil with higher water storage capacity, showing that soils need to be considered differently to assess tree vulnerability and tree growth potentialities.

Direct and delayed effects of water stress were monitored during 2009 drought and the following year. The transpiration drop-off that occurred during drought was partly maintained the following year (and maybe over a longer time), making difficult the tree recovery, which is dependent on the quantity of carbon reserves to renew needles and roots affected by drought. Such a postdrought effect on water fluxes cannot be represented by a stomatal conductance driven by the soil water content that is, in general, the main regulation process in soil vegetation atmosphere transfer models. Our results suggest that the roots dynamic and their capacity to take water from the soil were modified by the drought over at least 2 years. When trees suffered severe droughts, this property was then a key factor to understand the transpiration rate and the vulnerability of the trees. Such a regulation process must be confirmed and better documented before being implemented within models.

Transpiration and predawn water potential measurements have shown that the water stress occurred earlier with a stronger intensity on trees located on soil having the best water storage capacity. This confirms that water stress is a key factor in the silver fir declining process. The higher mortality of these trees can be explained by a stronger weakening during drought and then lower carbon reserves available to recover and for defenses. Moreover, it indicates that the root systems of trees growing on the best soil were not able to take benefit from the total water resources. Tree adjustments to their local environment, particularly concerning the root vertical distribution and the ratio between the root and aboveground systems might be an important factor to explain the tree vulnerability to drought.

Acknowledgments We thank B. Bes, A. Chapelet, N. Mariotte, F. Courdier, W. Brunetto, D. Gounelle, and A. Jouineau for their important help in taking all of the measurements in the field as well as G. Sappe, O. Marloie, J.F. Hanocq, and F. Tison for their technical support on the building of sensors and wiring. We also thank A. Granier, S. Rambal, C. Doussan, and L. Pages for several discussions that helped to understand the results and E. Dreyer and two anonymous reviewers who were very helpful to improve this manuscript.
Funding The research was funded by the project ANR-06-VULN-004 (Agence Nationale de Recherche) and by the Office National des Forêts (ONF) through a $\mathrm{PhD}$ grant.

\section{References}

Allen CD, Macalady AK, Chenchouni H, Bachelet D, McDowell N, Vennetier M, Kitzberger T, Rigling A, Breshears DD, Hogg EH, Gonzalez P, Fensham R, Zhang Z, Castro J, Demidova N, Lim J-H, Allard G, Running SW, Semerci A, Cobb N (2010) A global overview of drought and heat-induced tree mortality reveals emerging climate change risks for forests. For Ecol Manag 259:660-684

Aussenac G (2002) Ecology and ecophysiology of circum-Mediterranean firs in the context of climate change. Ann For Sci 59:823-832

Battipaglia G, Saurer M, Cherubini P, Siegwolf RTW, Cotrufo MF (2009) Tree rings indicate different drought resistance of a native (Abies alba Mill.) and nonnative (Picea abies (L.) Karst.) species co-occuring at a dry site in Southern Italy. For Ecol Manag 257:820-828

Becker M (1977) Contribution à l'étude de la transpiration et de l'adaptation à la sécheresse des jeunes plants résineux. exemple de 3 sapins du pourtour méditerranéen (Abies alba, A. nordmanniana, A. numidica). Ann For Sci 34:137-158

Bréda N, Huc R, Granier A, Dreyer E (2006) Temperate forest trees and stands under severe drought: a review of ecophysiological responses, adaptation processes and long-term consequences. Ann For Sci 63:625-644

Cailleret M, Davi H (2011) Effects of climate on diameter growth of co-occuring Fagus sylvatica and Abies alba along an altitudinal gradient. Trees 25:265-276. doi:10.1007/s00468-010-0503-0

Cailleret M, Nourtier M, Amm A, Gillmann M, Davi H (2012) Comparison of drought-induced decline and mortality processes on silver fir among three sites in Provence, south-east France. Ann For Sci (in press)

Cermak J, Nadezhina N, Meiresonne L, Ceulemans R (2008) Scots pine root distribution derived from radial sap flow patterns in stems of large leaning trees. Plant Soil 305:61-75

Cochard H, Cruiziat P, Tyree MT (1992) Use of positive pressures to establish vulnerability curves. Further support for the air-seeding hypothesis and implications for pressure-volume analysis. Plant Physiol 100:205-209

Davi H, Dufrêne E, Francois C, Maire GL, Loustau D, Bosc A, Rambal S, Granier A, Moors E (2006) Sensitivity of water and carbon fluxes to climate changes from 1960 to 2100 in European forest ecosystems. Agric For Meteorol 141:35-56

Delpierre N, Soudani K, François C, Köstner B, Pontallier JY, Nikinmaa E, Misson L, Aubinet M, Bernhofer C, Granier A, Grünwalds T, Heinesch B, Longdoz B, Ourcival JM, Rambal S, Vesala T, Dufrêne E (2009) Exceptional carbon uptake in European forests during the warm spring of 2007: a data-model analysis. Global Change Biol 15:1455-1474

Delzon S, Sartore M, Granier A, Loustau D (2004) Radial profiles of sap flow with increasing tree size in maritime pine. Tree Physiol 24:1285-1293

Dufrêne E, Davi H, François C, Maire GL, Dantec VL, Granier A (2005) Modelling carbon and water cycles in a beech forest. Part I: model description and uncertainty analysis on modelled NEE. Ecol Model 185:407-436

Fiora A, Cescatti A (2006) Diurnal and seasonal variability in radial distribution of sap flux density: implications for estimating stand transpiration. Tree Physiol 26:1217-1225

Gillmann M, Cailleret M, Boivin T, Nageleisen L-M, Davi H (2012) Contrasting effects of mistletoe and bark beetles on silver fir growth during decline process. Ann For Sci (in press) 
Guicherd P (1994) Water relations of European silver fir (Abies alba Mill) in 2 natural stands in the French Alps subject to contrasting climatic conditions. Ann For Sci 51:599-611

Heckathorn SA, DeLucia EH, Zielinski RE (1997) The contribution of drought-related decreases in foliar nitrogen concentration to decrease in photosynthsis capacity during and after drought in prairie grasses. Physiol Plantarum 101:173-182

Köstner B, Granier A, Cermak J (1998) Sapflow measurements in forest stands: methods and uncertainties. Ann For Sci 55:13-27

Kutscha NP, Sachs IB (1962) Color tests for differentiating heartwood and sapwood in certain softwood tree species. Report 2246. Forest Products Laboratory, Madison

Lebourgeois F, Lévy G, Aussenac G, Clerc B, Willm F (1998) Influence of soil drying on leaf water potential, photosynthesis, stomatal conductance and growth in two black pine varieties. Ann For Sci 55:287-299

Lebourgeois F, Rathgeber CBK, Ulrich E (2010) Sensitivity of French temperate coniferous forests to climate variability and extreme events (Abies alba, Picea abies and Pinus sylvestris). J Veg Sci 21:364-376

Limousin JM, Rambal S, Ourcival JM, Rocheteau A, Joffre R, Rodriguez-Cortina R (2009) Long-term transpiration change with rainfall decline in a Mediterranean Quercus ilex forest. Glob Change Biol 15:2163-2175

Lu P, Urban L, Zhao P (2004) Granier's thermal dissipation probe (TDP) method for measuring sap flow in trees: theory and practice. Acta Bot Sin 46:631-646

Mainiero R, Kazda M (2006) Depth-related fine root dynamics of Fagus sylvatica during exceptional drought. For Ecol Manag 237:135-142

Martinez-Vilalta J, Piñol J, Beven K (2002) A hydraulic model to predict drought-induced mortality in woody plants: an application to climate change in the Mediterranean. Ecol Model 155:127147

McDowell N, Sevanto S (2010) The mechanisms of carbon starvation: how, when, or does it even occur at all? New Phytol 186:264266

McElrone AJ, Pockman WT, Martinez-Vilalta J, Jackson RB (2004) Variation in xylem structure and function in stems and roots of trees to $20 \mathrm{~m}$ depth. New Phytol 163:507-517

Mencuccini M, Grace J (1995) Climate influences the leaf area/sapwood area ratio in Scots pine. Tree Physiol 15:1-10

Montagu KD, Woo KC (1999) Recovery of tree photosynthetic capacity from seasonal drought in the wet-dry tropics: the role of phyllode and canopy processes in Acacia auriculiformis. Aust J Plant Physiol $26: 135-145$
Nadezhdina N (2010) Integration of water transport pathways in a maple tree: responses of sap flow to branch severing. Ann For Sci 67 (107) doi:10.1051/forest/2009092

Nadezhdina N, Cermak J, Meiresonne L, Ceulemans R (2007) Transpiration of Scots pine in Flanders growing on soil with irregular substratum. For Ecol Manage 243:1-9

Nijland W, Meijde MVD, Addink EA, Jong SMD (2010) Detection of soil and vegetation water abstraction in a Mediterranean natural area using electrical resistivity tomography. Catena 81:209-216

Noilhan J, Mahfouf J-F (1996) The ISBA land surface parameterisation scheme. Global Planet Change 13:145-159

Nourtier M, Chanzy A, Granier A, Huc R (2011) Sap flow measurements by thermal dissipation method using cyclic heating: a processing method accounting for the non-stationary regime. Ann For Sci 68:1255-1264

Olesinki J, Lavigne MB, Krasowski MJ (2011) Effects of soil moisture manipulations on fine root dynamics in a mature balsam fir (Abies balsamea L. Mill.) forest. Tree Physiol 31:339-348

Pammenter NW, Willigen CV (1998) A mathematical and statistical analysis of the curves illustrating vulnerability of xylem to cavitation. Tree Physiol 18:589-593

Peguero-Pina JJ, Camarero JJ, Abadia A, Martin E, Gonzalez-Cascon R, Morales F, Gil-Pelegrin E (2007) Physiological performance of silver-fir (Abies alba Mill.) populations under contrasting climates near the south-western distribution limit of the species. Flora 202:226-236

Peñuelas J, Lloret F, Montana R (2001) Severe droughts effects on mediterranean woody flora in Spain. For Sci 47:214-218

Piovani P, Leonardi S, Magnani F, Menozzi P (2011) Variability of stomatal conductance in a small and isolated population of silver fir (Abies alba Mill.). Tree Physiol 31:500-507

Rambal S (1984) Water balance and pattern of root water uptake by Quercus coccifera L. evergreen scrub. Oecologia 62:18-25

Sala A, Piper F, Hoch G (2010) Physiological mechanisms of droughtinduced tree mortality are far from being resolved. New Phytol 186:274-281

Sarris D, Christodoulakis D, Körner C (2007) Recent decline in precipitation and tree growth in the eastern Mediterranean. Global Change Biol 13:1187-1200

Sperry JS, Adler FR, Campbell GS, Comstock JP (1998) Limitation of plant water use by rhizosphere and xylem conductance: results from a model. Plant Cell Envir 21:347-359

Zweifel R, Zimmermann L, Zeugin F, Newbery DM (2006) Intraannual radial growth and water relations of trees: implications towards a growth mechanism. J Exp Bot 57:1445-1459 